\title{
Pangan yang difortifikasi zat gizi mikro pada ibu hamil meningkatkan perkembangan motorik bayi
}

\author{
Provision of micronutrient-fortified supplementary foods in pregnant mother improves infant's motor \\ development
}

Bernatal Saragih', Hidayat Syarief ${ }^{2}$, Hadi Riyadi², Amini Nasoetion²

\begin{abstract}
Background: Many factors influence the growth and development of an infant but nutrition was undeniably one of the most important factors. One way to improve the nutritional status of infants was by providing supplementary foods fortified with multiple micronutrients to mothers during pregnancy. Nutritional interventions during pregnancy provided better nutrient reserves for mothers and fetus.

Objectives: To analyze the impact of multi micronutrient-fortified supplementary foods provision in pregnant mothers on motor development and anemia status of infants in three sub-districts of Bogor District namely: Leuwiliang, Leuwisadeng and Ciampea.

Methods: A total of 120 infants were followed up in a prospective cohort study. The subjects were divided into three groups, i.e: 40 infants in fortified group (pregnant mothers received supplementary foods (vermicelli, milk and biscuit) fortified with multi-nutrients i.e. iron, iodine, zinc, folic acid, vitamin C and vitamin A), 40 infants in non-fortified groups (pregnant mothers received non fortified foods) and 40 infants in the control groups (pregnant mothers did not receive any supplementary foods). Motor development was measured by methods developed by the Ministry of Health, Republic of Indonesia. Hb was measured by Cyanmethemoglobin method. Ancova and linear logistic regression were used to analyze the data.

Result: Provision of multi micronutrient-fortified supplementary foods in pregnant mothers substantially improves infant's motor development ( $77 \%$ better than other groups). In addition, supplementation of multi micronutrient-fortified foods in pregnant mothers reduced the rate of hemoglobin and hematocrit decline in infants up to the age of 6 months. There were no infants aged 6 months with $\mathrm{Hb}<90 \mathrm{~g} / \mathrm{L}$ in the fortified group, while in the non-fortified group and control group the prevalence of anemia was $8.3 \%$ and $11.11 \%$, respectively.

Conclusion: Provision of multi micronutrient-fortified supplementary foods in pregnant mothers improved infant's motor development.
\end{abstract}

KEY WORDS: multi micronutrients, pregnancy, infant, motor development, anemia

\begin{abstract}
ABSTRAK
Latar belakang: Banyak faktor yang mempengaruhi pertumbuhan dan perkembangan bayi, tetapi gizi merupakan faktor yang paling penting. Salah satu cara untuk memperbaiki status gizi bayi yaitu dengan pemberian pangan yang difortifikasi zat multi gizi mikro pada ibu selama proses kehamilan. Intervensi gizi pada masa kehamilan akan memberikan cadangan atau simpanan zat gizi yang lebih baik pada ibu dan janin.

Tujuan: Mengetahui dampak pemberian pangan yang difortifikasi zat multi gizi mikro pada ibu hamil terhadap perkembangan motorik dan status anemia bayi di tiga kecamatan yaitu Leuwiliang, Leuwisadeng, dan Ciampea Kabupaten Bogor.

Metode: Penelitian ini dilakukan dengan metode kohort prospektif dengan jumlah 120 bayi yang dibagi menjadi 3 kelompok, masing-masing terdiri dari 40 bayi yaitu kelompok fortifikasi, kelompok tanpa fortifikasi, dan kelompok kontrol. Kelompok fortifikasi yaitu 40 bayi yang ibunya saat hamil menerima pangan yang difortifikasi vitamin A, C, asam folat, besi, seng, dan iodium. Pengukuran perkembangan motorik bayi menggunakan metode yang dikembangkan oleh Departemen Kesehatan Republik Indonesia. Pengukuran kadar Hb mengunakan metode Cyanmeth. Uji Ancova untuk mengetahui adanya faktor perancu terhadap perkembangan motorik dan status anemia dan uji regresi logistik untuk mengetahui pengaruh pemberian pangan fortifikasi zat multi gizi mikro pada ibu hamil terhadap perkembangan motorik bayi. Hasil: Pemberian pangan fortifikasi zat multi gizi mikro pada ibu hamil memberikan respon perkembangan motorik bayi $77 \%$ lebih baik dibandingkan kelompok lainnya. Pangan fortifikasi pada penelitian ini lebih pada menahan laju penurunan $\mathrm{Hb}$ dan hematokrit bayi sampai usia 6 bulan. Tidak ditemukan bayi usia 6 bulan dengan Hb kurang dari $90 \mathrm{~g} / \mathrm{L}$ pada kelompok fortifikasi sedangkan pada kelompok tanpa fortifikasi dan kontrol ditemukan sebesar 8,3\% dan 11,11\%.

Kesimpulan: Pemberian pangan fortifikasi zat multi gizi mikro pada ibu hamil berpengaruh terhadap perkembangan motorik bayi dan lebih baik dibandingkan dengan kelompok tanpa fortifikasi dan kelompok kontrol.
\end{abstract}

KATA KUNCI: zat multi gizi mikro, ibu hamil, bayi, perkembangan motorik, anemia

\footnotetext{
${ }^{1}$ Korespondensi: Program Studi Teknologi Hasil Pertanian, Fakultas Pertanian Universitas Mulawarman, Jl. Pasir Balengkong Kampus Gunung Kelua, Samarinda 75119, e-mail: saragih_bernatal@yahoo.com

${ }^{2}$ Departemen Gizi Masyarakat, Fakultas Ekologi Manusia Institut Pertanian Bogor, Jl. Lingkar Kampus, Kampus IPB Dramaga Bogor 16680
} 


\section{PENDAHULUAN}

Kesehatan dan gizi ibu hamil yang baik merupakan kondisi yang sangat diperlukan bagi janin untuk menjadi sehat. Jika tidak, maka dari awal kehidupan manusia sampai pada kehidupan selanjutnya akan bermasalah. Masa kehamilan adalah periode yang sangat menentukan kualitas anak yang dilahirkan. Keadaan gizi ibu yang kurang baik sebelum hamil dan pada waktu hamil akan cenderung melahirkan bayi dengan berat badan lahir rendah (BBLR), bahkan kemungkinan bayi meninggal dunia. Hasil penelitian di Dhaka, Bangladesh menunjukkan bahwa anak yang dilahirkan dengan berat badan rendah berpotensi menjadi anak gizi kurang bahkan menjadi buruk (1). Gizi buruk pada bayi akan berdampak pada pertumbuhan dan perkembangannya.

Perkembangan motorik adalah perkembangan mengontrol gerakan-gerakan tubuh melalui kegiatan terkoordinasi antara susunan saraf pusat, saraf, dan otot (2). Badan Kependudukan dan Keluarga Berencana Nasional (BKKBN) menjelaskan tahap perkembangan gerak motorik kasar pada bayi yaitu umur satu bulan dapat melirikan mata ke kanan dan ke kiri, dua bulan dapat membalas senyum pada orang lain, tiga bulan dapat menegakkan kepala, empat bulan dapat miring sendiri, lima bulan dapat menelurkan tiga suara berbeda, dan enam bulan dapat meraih dan memegang benda kecil dihadapannya (3). Perkembangan motorik umumnya mudah diketahui oleh orang tua atau pengasuhnya. Keterlambatan perkembangan motorik merupakan gejala yang umum dijumpai pada gangguan perkembangan. Keterlambatan di bidang motorik juga merupakan gejala umum pada retardasi mental dan sering pula menjadi gejala awal dari gangguan belajar (4).

Perbandingan berbagai hasil studi perkembangan motorik bayi menunjukkan bahwa usia pencapaian perkembangan motorik bayi orang Indonesia rata-rata lebih tinggi dibandingkan dengan orang Amerika, Inggris, dan Nepal (5-7). Perkembangan bayi yang sangat menonjol pada umur 0 sampai 6 bulan adalah perkembangan motorik. Berdasarkan hasil pengukuran pada masa perkembangan selama satu tahun pertama, tiga bulan yang sangat pesat perkembangannya yaitu pada bulan ketiga, keenam, dan bulan kesepuluh (8).

Masalah gizi dan anemia di berbagai negara berkembang juga sangat tinggi. Gizi kurang dan anemia pada bayi akan mengganggu pertumbuhan dan perkembangannya. Menurut hasil laporan Departemen Kesehatan (Depkes), prevalensi anemia pada usia 6 bulan mencapai $61 \%$ dan meningkat menjadi $65 \%$ pada usia 12 bulan (9). Anemia pada anak akan menyebabkan penurunan perkembangan kognitif, motorik, dan perilaku $(10,11)$. Hasil penelitian di Zanzibar menunjukkan bahwa suplementasi besi dan folat pada bayi berumur $5-10$ bulan yang diamati milestone motoriknya yaitu umur waktu berjalan menunjukkan bahwa kecepatan (umur) waktu berjalan anak dipengaruhi suplementasi besi dan folat yang berhubungan dengan perbaikan status besi dan hemoglobin $(\mathrm{Hb})$ pada anak (12).

Intervensi gizi pada masa kehamilan akan memberikan cadangan atau simpanan zat gizi yang lebih baik pada ibu dan janin. Oleh karena itu, penelitian pemberian pangan yang difortifikasi zat multi gizi (vitamin $\mathrm{A}, \mathrm{C}$, asam folat, besi, seng, dan iodium) pada ibu hamil diharapkan menjadi salah satu cara untuk memperbaiki generasi yang akan datang. Tujuan penelitian ini adalah untuk menganalisis pengaruh pemberian pangan yang difortifikasi zat multi gizi pada ibu hamil terhadap perkembangan motorik bayi.

\section{BAHAN DAN METODE}

Penelitian ini dilaksanakan di tiga Kecamatan di Kabupaten Bogor yaitu Kecamatan Leuwiliang, Ciampea, dan Leuwisadeng pada bulan Februari 2006 sampai Agustus 2007. Populasi adalah semua ibu hamil di ketiga kecamatan tersebut kemudian dilakukan pengambilan sampel ibu hamil dengan kriteria umur 18-35 tahun, umur kehamilan 2-3 bulan, tidak merokok dan minum alkohol, tidak menderita penyakit kronis, keluarga miskin, dan anak yang dikandung adalah anak yang kedua sampai kelima. Kriteria eksklusi adalah ibu dari keluarga tidak miskin, menderita penyakit kronis, memiliki anak lebih dari 5 orang, perokok, dan kehamilan di atas tiga bulan.

Besar sampel minimal dihitung dengan menggunakan rumus rancangan eksperimental (13) dengan nilai standar deviasi (S) kadar $\mathrm{Hb}$ pada bayi sebesar 1,0 gr/dl, sebaran normal kekuatan $(Z \beta)$ 80\% $(0,84)$, sebaran normal $(Z \alpha)$ dengan selang kepercayaan $95 \%(1,96)$, perbedaan ratarata (d) kadar $\mathrm{Hb}$ sebesar $0,9 \mathrm{gr} / \mathrm{dL}$, dan perkiraan drop out $30 \%$ sehingga diperoleh jumlah sampel minimal masingmasing kelompok sebesar 40 bayi. Jumlah sampel yang diperoleh sebesar 210 orang, namun hanya 165 orang ibu hamil yang memenuhi kriteria dan kemudian dibagi dalam 3 kelompok perlakuan dengan jumlah sampel pada masingmasing kelompok perlakuan adalah 55 orang ibu hamil.

Kelompok pertama mendapatkan intervensi biskuit, bihun, dan susu yang difortifikasi dengan vitamin A, C, asam folat, besi, seng, dan iodium (fortifikasi/F); kelompok kedua mendapat intervensi biskuit, bihun, dan susu tanpa difortifikasi (tanpa fortifikasi/TF); dan kelompok ketiga tanpa menerima makanan tambahan (kontrol/K). Takaran saji setiap kali konsumsi untuk kelompok fortifikasi dan tanpa fortifikasi sebagai berikut: susu takaran per saji 35 $\mathrm{g}$ (1 kantong) dengan konsumsi per hari $70 \mathrm{~g}$ (2 kantong); biskuit takaran per saji $28 \mathrm{~g}$ (4 keping) dengan konsumsi per hari $56 \mathrm{~g}$ (8 keping); bihun takaran per saji $57 \mathrm{~g} \mathrm{(1}$ kantong) dengan konsumsi per hari $57 \mathrm{~g}$ (1 kantong). 
Susu dikonsumsi setiap hari sedangkan bihun dan biskuit bergantian sampai minggu ke-24 dengan selang waktu satu minggu. Minggu pertama diberi biskuit setiap hari maka minggu selanjutnya diberikan bihun dan seterusnya.

Setelah subjek penelitian melahirkan, dilakukan pengambilan sampel bayi dengan kriteria yaitu berat badan di atas $2500 \mathrm{~g}$, lahir normal, sehat, dan tidak kembar. Kemudian dilakukan pengamatan pertumbuhan dan perkembangan pada bayi lahir dengan menggunakan rancangan kohort prospektif mengikuti dari 0 sampai 6 bulan. Bayi yang memenuhi kriteria untuk penelitian sebanyak 120 dengan masing-masing sampel sesuai kelompok perlakuan sebanyak 40 bayi. Penelitian ini sudah memperoleh ethical clereance dari Komisi Etik Badan Penelitian dan Pengembangan Kesehatan Jakarta.

Variabel karakteristik keluarga yang diteliti meliputi pendidikan ibu dan suami (lama sekolah), pendapatan per kapita berdasarkan kategori keluarga miskin Kabupaten Bogor (miskin jika pendapatan kurang dari Rp 150.000 dan tidak miskin jika pendapatan lebih dari atau sama dengan Rp 150.000), pekerjaan ibu dan suami, dan jumlah anggota keluarga (anggota keluarga kecil jika $\leq 4$ orang dan besar jika $>4$ orang). Asupan ibu menyusui dan bayi diperoleh dengan metode recall 24 jam yang dilakukan dua kali yaitu pada usia bayi 3 bulan dan 6 bulan. Status gizi ibu menyusui diukur setiap bulan dengan penimbangan berat badan (BB) menggunakan timbangan bathroom scale dan tinggi badan diukur pada saat bulan pertama ibu hamil menggunakan microtoise (ketelitian 0,1 cm) kemudian dikategorikan berdasarkan indeks massa tubuh (IMT kurus $<18,5 \mathrm{~kg} / \mathrm{m}^{2}$, normal $18,5-22,9 \mathrm{~kg} / \mathrm{m}^{2}$, dan gemuk $\geq 23 \mathrm{~kg} / \mathrm{m}^{2}$ ). Pengukuran panjang badan (PB) bayi dengan menggunakan dua papan bersiku dan meteran (ketelitian 0,1 cm) sedangkan berat badan dengan baby scale (ketelitian $50 \mathrm{~g}$ ). Berat badan dan panjang badan digunakan untuk menentukan status gizi bayi setiap bulan. Status gizi bayi dikategorikan berdasarkan World Health Organization (WHO) 2006 dengan kriteria status gizi bayi underweight jika Z-Skor BB/U kurang dari -2SD dan stunting jika Z-Skor PB/U kurang dari -2SD. Pertumbuhan panjang lutut bayi diukur pada usia 6 bulan menggunakan knemometer dengan ketelitian $0,1 \mathrm{~cm}$.

Morbiditas atau tingkat kesakitan pada bayi diukur dengan menanyakan pada ibu jenis penyakit. Setelah itu diberi skor jenis penyakit berdasarkan tingkat keparahannya dengan kriteria yang paling rendah untuk penyakit kulit (bisul, kulit merah, gatal) dan tertinggi (skor 80 ) untuk muntaber (rendah jika total skor $<146,7$ dan tinggi jika total skor $\geq 146,7)(14)$. Status anemia diketahui dengan mengukur kadar $\mathrm{Hb}$ darah bayi pada umur 6 bulan dengan metode Cyanmeth dan dikategorikan menjadi anemia $(\mathrm{Hb}$ $<110 \mathrm{~g} / \mathrm{L})$ dan tidak anemia $(\mathrm{Hb} \geq 110 \mathrm{~g} / \mathrm{L})$.

Tabel 1. Instrumen deteksi dini penyimpangan perkembangan pada bayi

\begin{tabular}{|c|c|c|c|c|}
\hline No & \multicolumn{4}{|l|}{ Perkembangan motorik bayi umur 3 bulan } \\
\hline 1 & $\begin{array}{l}\text { Pada waktu bayi telentang, apakah masing-masing lengan dan tungkai bergerak dengan } \\
\text { mudah? Jawab TIDAK bila salah satu atau kedua tungkai atau lengan bayi bergerak tak } \\
\text { terarah/tak terkendali }\end{array}$ & Gerakan kasar & $\mathrm{Ya}$ & Tidak \\
\hline 2 & $\begin{array}{l}\text { Pada waktu bayi telentang, apakah ia dapat mengikuti gerakan anda dengan menggerakkan } \\
\text { kepalanya dari kanan/kiri ke tengah? }\end{array}$ & Gerakan halus & $\mathrm{Ya}$ & Tidak \\
\hline 3 & $\begin{array}{l}\text { Pada waktu bayi telentang, apakah ia dapat mengikuti gerakan anda dengan menggerakkan } \\
\text { kepalanya dari satu sisi hampir sampai pada sisi yang lain? }\end{array}$ & Gerakan halus & $\mathrm{Ya}$ & Tidak \\
\hline 4 & $\begin{array}{l}\text { Pada waktu bayi telungkup di alas yang datar, apakah ia dapat } \\
\text { mengangkat kepalanya? }\end{array}$ & Gerakan kasar & Ya & Tidak \\
\hline 5 & $\begin{array}{l}\text { Pada waktu bayi telungkup di alas yang datar, apakah ia dapat } \\
\text { mengangkat kepalanya sehingga membentuk sudut } 45^{\circ} \text { ? }\end{array}$ & Gerakan kasar & $\mathrm{Ya}$ & Tidak \\
\hline 6 & $\begin{array}{l}\text { Pada waktu bayi telungkup di alas yang datar, apakah ia dapat } \\
\text { mengangkat kepalanya dengan tegak? }\end{array}$ & Gerakan kasar & Ya & Tidak \\
\hline \multicolumn{5}{|c|}{ Perkembangan motorik bayi umur 6 bulan } \\
\hline 7 & $\begin{array}{l}\text { Pada waktu bayi telentang, apakah ia dapat mengikuti gerakan anda dengan menggerakkan } \\
\text { kepala sepenuhnya dari satu sisi ke sisi yang lain? }\end{array}$ & Gerakan halus & $\mathrm{Ya}$ & Tidak \\
\hline 8 & Dapatkah bayi mempertahankan posisi kepala dalam keadaan tegak stabil? & Gerakan kasar & Ya & Tidak \\
\hline 9 & $\begin{array}{l}\text { Sentuhkan pensil di punggung tangan atau ujung jari bayi (jangan meletakkan di atas telapak } \\
\text { tangan bayi). Apakah bayi dapat menggenggam pensil selama beberapa detik? }\end{array}$ & Gerakan halus & $\mathrm{Ya}$ & Tidak \\
\hline 10 & $\begin{array}{l}\text { Ketika bayi telungkup di alas datar, apakah ia dapat mengangkat dada dengan kedua } \\
\text { lengannya? }\end{array}$ & Gerakan kasar & Ya & Tidak \\
\hline 11 & Pernahkah bayi berbalik paling sedikit dua kali, dari telentang ke telungkup atau sebaliknya? & Gerakan kasar & Ya & Tidak \\
\hline 12 & $\begin{array}{l}\text { Dapatkah bayi mengarahkan matanya pada benda kecil sebesar kacang, kismis atau uang } \\
\text { logam? }\end{array}$ & Gerakan halus & $\mathrm{Ya}$ & Tidak \\
\hline 13 & $\begin{array}{l}\text { Dapatkah bayi meraih mainan yang diletakkan agak jauh namun masih berada dalam } \\
\text { jangkauan tangannya? }\end{array}$ & Gerakan halus & Ya & Tidak \\
\hline 14 & $\begin{array}{l}\text { Pada posisi bayi telentang, pegang kedua tangannya lalu tarik perlahan-lahan keposisi duduk. } \\
\text { Dapatkah bayi mempertahankan lehernya secara kaku? }\end{array}$ & Gerakan kasar & $\mathrm{Ya}$ & Tidak \\
\hline
\end{tabular}


Pengukuran pengasuhan dilakukan dengan mengamati dan menanyakan pada ibu tentang pengasuhan bayi yang dilakukan meliputi asuh makan, asuh bermain, dan asuh kesehatan. Pengasuhan dihitung berdasarkan skor aktual yang diperoleh dibagi skor total yang seharusnya kemudian dikelompokkan menjadi kurang (skor $\leq 60 \%$ ), sedang (skor 60 $-80 \%$ ), dan baik (skor $>80 \%$ ). Lama pemberian ASI ekslusif diukur berdasarkan jumlah bulan dan hari ibu memberikan ASI eksklusif pada bayi dengan wawancara menggunakan kuesioner. Perkembangan motorik kasar dan halus diamati langsung dengan menggunakan instrumen deteksi dini penyimpangan perkembangan yang dikembangkan oleh Departemen Kesehatan (15). Hasilnya dikategorikan berdasarkan persentase pencapaian tugas perkembangan dengan kategori kurang jika kurang dari $60 \%$, sedang jika sama dengan $60-80 \%$, dan baik jika lebih besar dari $80 \%$. Instrumen deteksi dini penyimpangan perkembangan terdiri dari 14 pertanyaan tugas perkembangan motorik pada umur 3 bulan dan 6 bulan (Tabel 1).

Uji Ancova dilakukan untuk mengetahui confounding factoryang mempengaruhi perkembangan motorik dan status anemia. Uji regresi logistik digunakan untuk mengetahui pengaruh pemberian pangan fortifikasi pada ibu hamil terhadap perkembangan motorik dan status anemia bayi.
HASIL

\section{Karakteristik keluarga}

Karakteristik keluarga menunjukkan perbedaan yang tidak bermakna kecuali untuk pendidikan ibu (Tabel 2). Hasil uji korelasi Pearson menunjukkan hubungan positif dan sangat bermakna antara pengasuhan dengan pendidikan ibu $(r=0,256 ; p=0,000)$, pendidikan ayah $(r=0,240 ; p=0,010)$, dan pendapatan per kapita keluarga $(r=0,215 ; p=0,020)$. Sebaliknya, jika jumlah anggota keluarga semakin besar maka pengasuhan pada bayi semakin rendah $(r=-0,053 ; p=0,568)$.

\section{Pengasuhan dan lama pemberian ASI eksklusif}

Skor pengasuhan setelah dikategorikan menunjukkan $56,3 \%$ pengasuhan cukup dan $43,7 \%$ pengasuhan baik. Hasil uji Anova menunjukkan tidak ada perbedaan yang bermakna $(p=0,414)$ pada pengasuhan bayi antara ketiga kelompok. Persentase bayi yang menerima ASI eksklusif ( 6 bulan) hanya sebesar 3,34\% (Gambar 1). Rerata volume ASI untuk kelompok fortifikasi sebesar 496,4 $\pm 143,2 \mathrm{ml} /$ hari, tanpa fortifikasi 490,7 $\pm 128,6 \mathrm{ml} / \mathrm{hari}$, dan kelompok kontrol 466,6 $\pm 155,3 \mathrm{ml} /$ hari. Pengasuhan berhubungan

Tabel 2. Karakteristik keluarga dan bayi

\begin{tabular}{lccccc}
\hline \multicolumn{1}{c}{ Karakteristik keluarga } & $\begin{array}{c}\mathbf{F} \\
\mathbf{( n = 4 0 )}\end{array}$ & $\begin{array}{c}\text { TF } \\
(\mathbf{n = 4 0 )}\end{array}$ & $\begin{array}{c}\mathbf{K} \\
(\mathbf{n = 4 0 )}\end{array}$ & $\begin{array}{c}\text { Total } \\
(\mathbf{n = 1 2 0})\end{array}$ & $\mathbf{p}$ \\
\hline Besar keluarga & $5,0 \pm 1,2$ & $5,1 \pm 1,5$ & $5,0 \pm 1,0$ & $5,05 \pm 1,27$ & 0,899 \\
Usia ibu (tahun) & $28,3 \pm 4,7$ & $28,5 \pm 4,0$ & $27,6 \pm 4,8$ & $28,1 \pm 4,5$ & 0,644 \\
Usia ayah (tahun) & $33,7 \pm 5,5$ & $32,8 \pm 4,2$ & $33,8 \pm 6,6$ & $33,5 \pm 5,4$ & 0,682 \\
Pendidikan ibu (tahun) & $6,5 \pm 1,9^{\mathrm{a}}$ & $6,7 \pm 1,5^{\mathrm{ab}}$ & $7,5 \pm 2,3^{\mathrm{b}}$ & $6,9 \pm 2,0$ & 0,050 \\
Pendidikan ayah (tahun) & $6,9 \pm 2,0$ & $7,6 \pm 1,5$ & $6,9 \pm 62,0$ & $7,1 \pm 2,0$ & 0,224 \\
Pendapatan perkapita (ribu rupiah) & $123,13 \pm 51,04$ & $113,07 \pm 39,62$ & $126,16 \pm 53,53$ & $120,66 \pm 48,41$ & 0,468 \\
\hline
\end{tabular}

Keterangan: $\mathrm{F}=$ kelompok fortifikasi; $\mathrm{TF}=$ kelompok tanpa fortifikasi; $\mathrm{K}=$ kelompok kontrol; ${ }^{\mathrm{a}, \mathrm{b}}$ angka yang diikuti huruf yang sama pada baris yang sama menunjukkan tidak ada perbedaan yang nyata antar kelompok

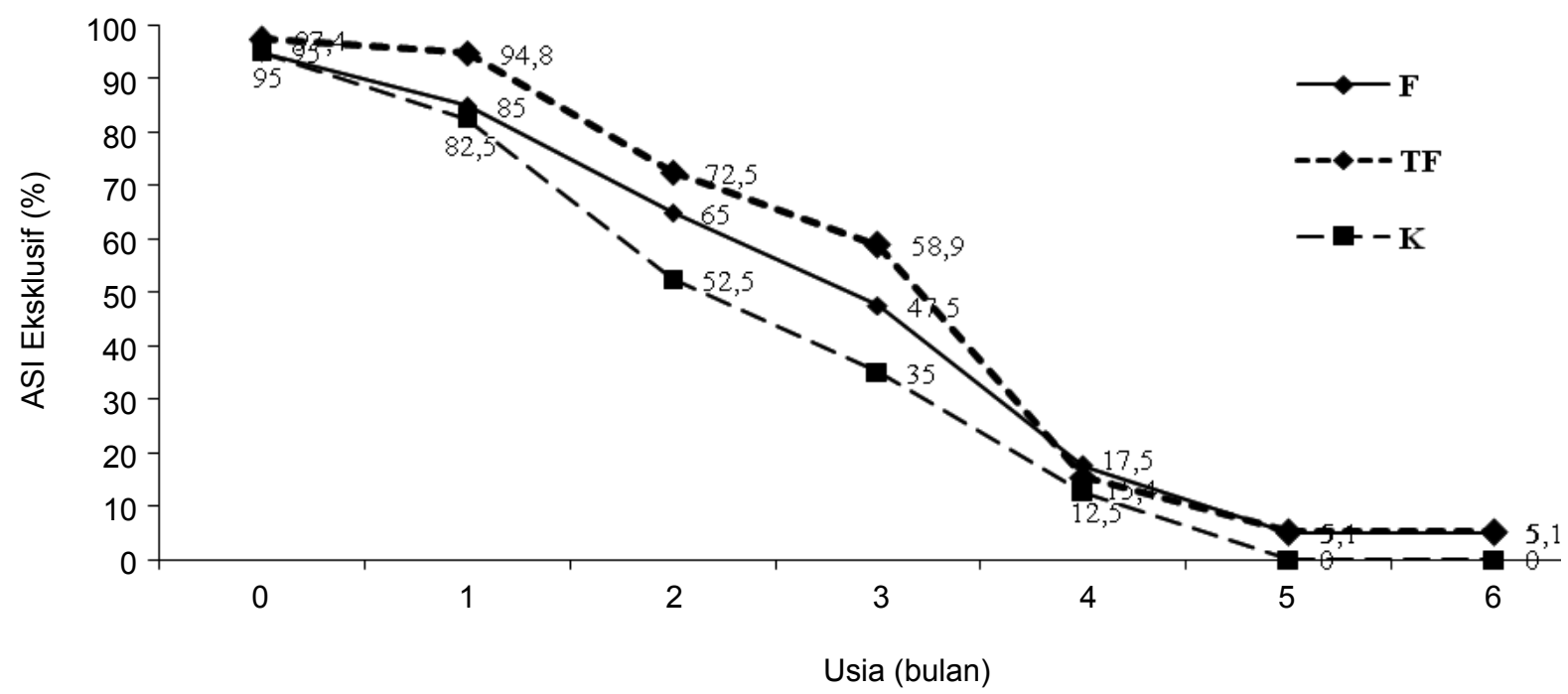

Gambar 1. Persentase lama pemberian ASI eksklusif 
Tabel 3. Tingkat kecukupan gizi bayi pada usia 6 bulan

\begin{tabular}{cccccc}
\hline $\begin{array}{c}\text { Asupan dan tingkat } \\
\text { kecukupan }\end{array}$ & $\begin{array}{c}\mathbf{F} \\
(\mathbf{n = 3 8 )}\end{array}$ & $\begin{array}{c}\mathbf{T F} \\
(\mathbf{n = 3 7 )}\end{array}$ & $\begin{array}{c}\mathbf{K} \\
(\mathbf{n = 4 0})\end{array}$ & $\begin{array}{c}\text { Rerata } \\
(\mathbf{n = 1 1 5})\end{array}$ & $\mathbf{p}$ \\
\hline Energi total (kkal) & $492 \pm 106$ & $494 \pm 122$ & $491 \pm 131$ & $492,3 \pm 119$ & 0,822 \\
Kecukupan (\%) & $89,5 \pm 13,1$ & $89,9 \pm 13,4$ & $89,4 \pm 14,3$ & $89,6 \pm 12,7$ & 0,870 \\
Protein total (g) & $8,9 \pm 1,8$ & $8,6 \pm 2,6$ & $8,4 \pm 2,6$ & $8,6 \pm 2,4$ & 0,631 \\
Kecukupan (\%) & $89,2 \pm 18,8$ & $86,8 \pm 24,5$ & $84,3 \pm 27,0$ & $86,3 \pm 24,0$ & 0,463 \\
Besi total (mg) & $1,95 \pm 0,8$ & $1,64 \pm 1,0$ & $1,73 \pm 0,9$ & $1,77 \pm 0,9$ & 0,188 \\
Kecukupan $(\%)$ & $79,1 \pm 20,3$ & $70,9 \pm 25,5$ & $71,5 \pm 26,0$ & $73,8+24,1$ & 0,250 \\
\hline
\end{tabular}

Keterangan: $\mathrm{F}=$ kelompok fortifikasi; $\mathrm{TF}=$ kelompok tanpa fortifikasi; $\mathrm{K}=$ kelompok kontrol

positif dengan perkembangan motorik $(r=0,463 ; p=0,010)$. Semakin baik pengasuhan bayi terutama stimulasi tugastugas perkembangan maka perkembangan motorik bayi semakin baik.

\section{Morbiditas dan tingkat kecukupan gizi bayi}

Jenis penyakit yang paling dominan pada bayi adalah infeksi saluran pernafasan akut (ISPA) dan diare. Frekuensi sakit ISPA tertinggi sebanyak 5 kali dan diare 3 kali (kontrol) yang dialami seorang bayi dalam 6 bulan terakhir. Frekuensi sakit yang dialami bayi dari usia 0-6 bulan tanpa membedakan jenis penyakit yaitu yang tertinggi terdapat pada bayi kelompok kontrol sebanyak 8 kali sakit. Hasil uji Anova menunjukkan terdapat perbedaan yang bermakna pada rata-rata tingkat morbiditas bayi usia 0-6 bulan antar kelompok perlakuan $(p=0,001)$. Tingkat morbiditas bayi tertinggi sampai terendah adalah kelompok kontrol $(166,3 \pm 134,0)$, tanpa fortifikasi $(113,3 \pm 86,2)$, dan fortifikasi $(91,2 \pm 74,7)$.

Hasil uji Anova menunjukkan tidak terdapat perbedaan yang bermakna asupan gizi bayi pada ketiga kelompok perlakuan (Tabel 3). Hasil uji korelasi Pearson menunjukkan hubungan yang positif dan bermakna antara asupan besi dengan pertumbuhan linier $(r=0,262$; $p=0,005)$, pertumbuhan panjang lutut $(r=0,271 ; p=0,003)$, dan kadar $\mathrm{Hb}(r=0,243 ; p=0,012)$. Namun, berhubungan tidak bermakna dengan berat badan $(r=0,154 ; p=0,099)$ dan perkembangan motorik $(r=0,172 ; p=0,065)$. Hasil ini menunjukkan asupan besi lebih responsif terhadap pertumbuhan linier, pertambahan panjang lutut, dan kadar $\mathrm{Hb}$ dibandingkan dengan pertambahan berat badan dan perkembangan motorik bayi.

\section{Tingkat kecukupan gizi dan status gizi ibu}

Tingkat kecukupan zat gizi ibu menyusui antar kelompok menunjukkan tidak terdapat perbedaan yang bermakna $(p>0,05)$. Rerata tingkat kecukupan zat gizi pada ketiga kelompok yaitu di atas $80 \%$ kecukupan energi. Namun, untuk tingkat kecukupan protein di bawah $62 \%$ dan zat besi di bawah $46 \%$.

Status gizi (IMT) ibu menyusui antar kelompok menunjukkan perbedaan yang bermakna $(p=0,027)$ dengan
IMT tertinggi pada kelompok tanpa fortifikasi $\left(21,9 \pm 2,6 \mathrm{~kg} / \mathrm{m}^{2}\right)$, kontrol $\left(21,3 \pm 2,1 \mathrm{~kg} / \mathrm{m}^{2}\right)$ diikuti kelompok fortifikasi $(20,6 \pm 1,8$ $\mathrm{kg} / \mathrm{m}^{2}$ ). Perbedaan IMT ibu menyusui ini juga didukung dengan penurunan berat badan ibu. Rerata penurunan berat badan tertinggi pada ibu menyusui yaitu pada kelompok fortifikasi sebesar 2,67 kg kemudian kelompok kontrol 2,20 $\mathrm{kg}$, dan kelompok tanpa fortifikasi $1,32 \mathrm{~kg}$. Penurunan berat badan ibu pada kelompok fortifikasi terdapat pada kisaran 2,6-7,9 kg.

\section{Status anemia (Hb dan hematokrit)}

Kadar $\mathrm{Hb}$ bayi pada kelompok fortifikasi berkisar antara 95,7-120,0 g/L, kelompok tanpa fortifikasi antara 83,0-123,2 g/L, dan kelompok kontrol antara 70,6-120,3 $\mathrm{g} / \mathrm{L}$. Persentase bayi anemia $(\mathrm{Hb}<110 \mathrm{~g} / \mathrm{L})$ yang tertinggi terdapat pada kelompok kontrol yaitu 63,9\% kemudian kelompok fortifikasi $47,2 \%$ dan terendah pada kelompok tanpa fortifikasi yaitu 44,4\%. Hasil uji Ancova menunjukkan tidak terdapat perbedaan yang bermakna $(p=0,391)$ kadar $\mathrm{Hb}$ bayi antara ketiga kelompok perlakuan. Sedangkan persentase bayi anemia berdasarkan kadar hematokrit $(\mathrm{Ht}<33 \%)$ pada kelompok kontrol adalah yang tertinggi yaitu sebesar $38,9 \%$ kemudian kelompok tanpa fortifikasi sebesar $30,6 \%$ dan terendah adalah kelompok fortifikasi sebesar $27,8 \%$.

\section{Perkembangan motorik}

Bayi dalam penelitian ini tidak ada yang termasuk dalam kategori perkembangan motorik yang terlambat. Persentase tertinggi bayi yang termasuk dalam perkembangan motorik yang baik tanpa membedakan status ASI terdapat pada kelompok fortifikasi $(95,0 \%)$ kemudian diikuti kelompok tanpa fortifikasi $(84,6 \%)$ dan kelompok kontrol $(82,5 \%)$.

Hasil yang sama juga diperoleh berdasarkan status pemberian ASI dan perlakuan. Persentase perkembangan motorik bayi yang termasuk kategori baik, cenderung lebih besar pada kelompok yang memperoleh ASI saja sampai 3 bulan dan ibu ketika hamil menerima pangan fortifikasi dibandingkan tanpa fortifikasi dan kontrol yang juga memperoleh ASI saja sampai di atas 3 bulan (Tabel 4). Hal ini menunjukkan pemberian pangan fortifikasi ketika ibu hamil yang dilanjutkan dengan pemberian ASI 
Tabel 4. Sebaran sampel berdasarkan perkembangan motorik, status pemberian ASI, dan perlakuan

\begin{tabular}{|c|c|c|c|c|c|c|c|c|c|}
\hline \multirow[t]{2}{*}{ Status ASI } & \multirow{2}{*}{$\begin{array}{l}\text { Perkembangan } \\
\text { motorik }\end{array}$} & \multicolumn{2}{|c|}{$\begin{array}{c}F \\
(n=40)\end{array}$} & \multicolumn{2}{|c|}{$\begin{array}{c}\text { TF } \\
(n=39)\end{array}$} & \multicolumn{2}{|c|}{$\begin{array}{c}K \\
(n=40)\end{array}$} & \multicolumn{2}{|c|}{$\begin{array}{c}\text { Total } \\
(n=119)\end{array}$} \\
\hline & & $\mathbf{n}$ & $\%$ & $\mathbf{n}$ & $\%$ & $\mathbf{n}$ & $\%$ & $\mathbf{n}$ & $\%$ \\
\hline \multirow{3}{*}{$\begin{array}{l}\text { Sudah diberi makanan dan minuman selain } \\
\text { ASI pada usia di bawah } 3 \text { bulan }\end{array}$} & Sedang & 1 & 7,1 & 2 & 22,2 & 5 & 23,8 & 8 & 18,2 \\
\hline & Baik & 13 & 92,9 & 7 & 77,8 & 16 & 76,2 & 36 & 81,8 \\
\hline & Total & 14 & 100 & 9 & 100 & 21 & 100 & 44 & 100 \\
\hline \multirow{3}{*}{$\begin{array}{l}\text { ASI saja sampai } \\
\text { di atas } 3 \text { bulan }\end{array}$} & Sedang & 1 & 3,8 & 4 & 13,3 & 2 & 10,5 & 7 & 9,3 \\
\hline & Baik & 25 & 96,2 & 26 & 86,7 & 17 & 89,5 & 68 & 90,6 \\
\hline & Total & 26 & 100 & 30 & 100 & 19 & 100 & 75 & 100 \\
\hline
\end{tabular}

Keterangan: Kategori perkembangan motorik terlambat $(<60 \%)$, sedang $(60-80 \%)$, dan baik $(>80 \%)$

$\mathrm{F}=$ kelompok fortifikasi; $\mathrm{TF}=$ kelompok tanpa fortifikasi; $\mathrm{K}=$ kelompok kontrol

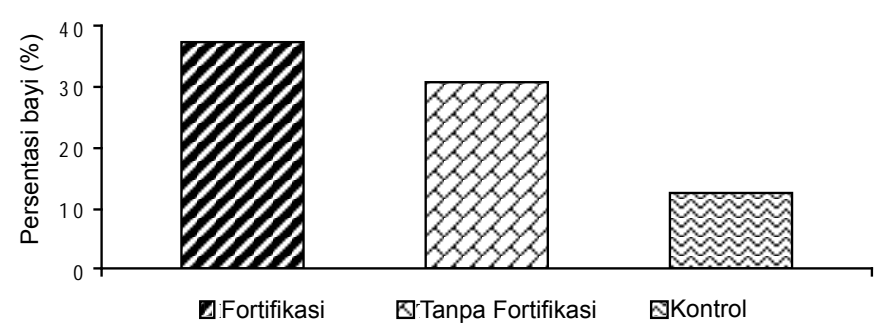

Gambar 2. Persentase bayi pada usia 6 bulan yang mampu mengikuti semua tugas perkembangan

saja sampai di atas 3 bulan menghasilkan perkembangan motorik anak yang lebih baik. Rerata skor perkembangan motorik bayi juga menunjukkan hasil yang sama yaitu skor perkembangan motorik tertinggi terdapat pada kelompok fortifikasi, walaupun hasil analisis Anacova menunjukkan tidak terdapat perbedaan yang bermakna $(p=0,087)$. Rerata skor perkembangan motorik bayi pada kelompok fortifikasi adalah $91,61 \pm 7,2$; kelompok tanpa fortifikasi $90,29 \pm 7,77$; dan kelompok kontrol 88,03+6,05. Persentase bayi yang mampu mengikuti semua tugas perkembangan motorik (100\%) paling banyak ditemukan pada kelompok fortifikasi sebesar 37,5\% kemudian pada kelompok tanpa fortifikasi sebesar $30,8 \%$ dan terendah pada kelompok kontrol yaitu 12,5\% (Gambar 2). Hasil ini juga didukung oleh data kualitatif bahwa ibu yang menerima pangan fortifikasi mengatakan gerakan bayi mereka lebih aktif sewaktu dalam rahim jika dibandingkan dengan kehamilan sebelumnya.

\section{Faktor-faktor yang mempengaruhi perkembangan motorik bayi}

Hasil analisis regresi logistik (Tabel 5) menunjukkan bahwa faktor-faktor yang mempengaruhi terjadinya respon perkembangan motorik yang baik pada bayi adalah pemberian pangan fortifikasi pada ibu hamil dan tingkat morbiditas. Bayi dari kelompok ibu yang diberi pangan (biskuit, bihun, dan susu) yang difortifikasi dengan zat multi gizi mikro (vitamin A, C, folat, besi, seng, dan iodium) $82 \%$ lebih baik perkembangan motoriknya dibandingkan dengan kelompok kontrol.
Tabel 5. Faktor-faktor yang mempengaruhi perkembangan motorik bayi

\begin{tabular}{lccc}
\hline \multirow{2}{*}{ Variabel pengaruh } & \multicolumn{3}{c}{ Perkembangan motorik baik } \\
\cline { 2 - 4 } & OR & $\mathbf{9 5 \%} \mathbf{~ C ~}$ & $\mathbf{p}$ \\
\hline Pangan fortifikasi & & & \\
(F:K) & 0,18 & $0,07-0,47$ & 0,000 \\
(F:TF) & 0,22 & $0,03-1,52$ & 0,124 \\
Skor morbiditas $(<146,7)$ & 0,34 & $0,1-1,09$ & 0,035 \\
\hline
\end{tabular}

Keterangan:

Pangan fortifikasi (F); TF (Pangan tanpa fortifikasi); Kontrol (K)

\section{BAHASAN}

Hasil uji korelasi Pearson menunjukkan hubungan yang positif tetapi tidak bermakna $(p>0,05)$ antara pendidikan ibu dan ayah, pekerjaan ayah, dan pendapatan keluarga dengan perkembangan motorik bayi. Hasil ini menunjukkan bahwa peranan pendidikan orang tua, pekerjaan, dan pendapatan keluarga tidak memberikan pengaruh yang kuat terhadap perkembangan motorik bayi. Perkembangan motorik bayi umumnya dipengaruhi oleh status gizi. Bayi dengan gizi kurang atau gizi buruk memiliki perkembangan motorik yang kurang baik. Bayi yang obesitas cenderung memiliki perkembangan motorik kasar yang lebih rendah dibandingkan bayi dengan gizi baik.

Pangan fortifikasi pada penelitian ini lebih pada menahan laju penurunan $\mathrm{Hb}$ bayi sampai usia bayi 6 bulan. Bayi pada kelompok tanpa fortifikasi yang memiliki kadar $\mathrm{Hb}$ kurang dari $90 \mathrm{~g} / \mathrm{L}$ pada usia 6 bulan sebesar $8,3 \%$ dan kelompok kontrol sebesar $11,1 \%$, sedangkan bayi pada kelompok fortifikasi tidak ada yang memiliki kadar $\mathrm{Hb}$ kurang dari $90 \mathrm{~g} / \mathrm{L}$. Hal tersebut sesuai dengan kriteria $\mathrm{Hb}$ menurut usia yaitu pada usia 6-23 bulan $\mathrm{Hb}$ dikategorikan kurang jika $\mathrm{Hb}$ kurang dari $90 \mathrm{~g} / \mathrm{L}$, margin antara 90-99 g/L, dan cukup jika $\mathrm{Hb}$ lebih dari atau sama dengan $100 \mathrm{~g} / \mathrm{L}$ (16). Jika dikategorikan berdasarkan $\mathrm{Hb}$ cukup (100 g/L) maka persentase tertinggi kejadian anemia bayi terdapat pada kelompok kontrol 27,8\% kemudian kelompok tanpa fortifikasi $25 \%$ dan diikuti kelompok fortifikasi sebesar 5,6\%. Hal ini diduga disebabkan oleh ketersediaan zat gizi pada bayi kelompok fortifikasi lebih 
baik dibandingkan kedua kelompok lainnya. Intervensi gizi pada masa kehamilan juga memberikan cadangan atau simpanan zat gizi yang lebih baik pada ibu dan janin. Intervensi gizi ini diduga dapat meningkatkan simpanan zat besi dalam bentuk ferritin atau hemosiderin dalam hati dan darah, seng dalam bentuk a-macroglobulin, asam folat dalam bentuk poliglutamat, dan iodium di tiroid dalam bentuk triglobulin.

Status anemia berdasarkan hematokrit juga memiliki pola yang sama dengan $\mathrm{Hb}$ bahwa rata-rata persentase hematokrit pada bayi lebih tinggi pada kelompok fortifikasi dibandingkan dengan kelompok tanpa fortifikasi dan kontrol. Namun, hasil uji dengan Ancova juga menunjukkan tidak terdapat perbedaan yang bermakna $(p=0,745)$ kadar hematokrit antara ketiga kelompok perlakuan.

Hasil analisis regresi logistik pada penelitian ini menunjukkan bahwa faktor-faktor yang mempengaruhi status anemia pada bayi usia 6 bulan adalah jenis kelamin dan asupan besi. Hasil ini menunjukkan bahwa bayi perempuan memiliki risiko mengalami anemia 0,42 kali lebih besar dibandingkan dengan bayi laki-laki $(\mathrm{OR}=0,42 ; 95 \% \mathrm{Cl}: 0,18-$ $0,94 ; p=0,034)$. Selain itu, bayi laki-laki rata-rata lebih kuat menyusu ASI (data kualitatif) dibandingkan dengan bayi perempuan. Dalam penelitian ini juga ditemukan rerata proporsi bayi laki-laki dengan volume konsumsi ASI per hari di atas $500 \mathrm{ml} /$ hari lebih tinggi $(47,4 \%)$ dibandingkan bayi perempuan (45,0\%). Demikian juga proporsi asupan besi bayi laki-laki di atas $70 \%$ angka kecukupan gizi (AKG) lebih tinggi (60\%) dibandingkan dengan bayi perempuan (45,9\%).

Bayi yang memiliki asupan besi di bawah $70 \%$ AKG mengalami kejadian anemia 3,5 kali lebih besar dibandingkan dengan bayi yang memiliki asupan besi di atas $70 \%$ AKG $(\mathrm{OR}=3,50 ; 95 \% \mathrm{Cl}: 1,21-10,11 ; p=0,021)$. Asupan besi pada bayi dalam penelitian ini berasal dari ASI dan makanan bayi. Dalam penelitian ini ditemukan bahwa rata-rata sumbangan besi dari ASI 2 kali lebih tinggi dari makanan pendamping air susu ibu (MP ASI). Menurut penelitian di Afrika Barat konsumsi besi akan mempengaruhi kadar besi dalam tubuh yang ditunjukkan dengan kadar $\mathrm{Hb}$ atau ferritin darah (17).

Status besi ibu selama hamil berpengaruh terhadap simpanan besi bayi selama beberapa bulan setelah melahirkan. Suplementasi besi terhadap ibu hamil berhubungan dengan status besi bayi pada usia 2 bulan. Hal ini disebabkan ketersediaan besi ibu hamil digunakan untuk pertumbuhan janin selama proses kehamilan. Semakin baik ketersediaan besi atau $\mathrm{Hb}$ ibu hamil maka akan meningkatkan ketersediaan besi pada janin yang disalurkan melalui plasenta ibu. Sebaliknya, ibu hamil yang kadar $\mathrm{Hb}$-nya tidak normal sehingga ketersediaan besinya sangat rendah dapat meningkatkan risiko morbiditas maupun mortalitas ibu dan kemungkinan melahirkan bayi dengan BBLR dan prematur (18). Besi dibutuhkan dalam sirkulasi sebagai komponen $\mathrm{Hb}$ yang terlibat dalam pengangkutan oksigen. Penurunan sel darah merah dan penurunan aktivitas eryhtropoietic adalah hasil dari penurunan metabolisme jaringan yang berhubungan dengan peranan besi sebagai kofaktor esensial metabolik (19).

Hasil analisis menunjukkan tidak ada perbedaan bermakna pada perkembangan motorik antar kelompok $(p=0,087)$ yang sudah dikontrol dengan jenis kelamin, asupan energi, protein, besi, pengasuhan, dan tingkat kesakitan bayi. Akan tetapi, perkembangan motorik berkorelasi positif dengan pemberian pangan fortifikasi $(r=0,476 ; p=0,000)$, pertambahan panjang badan $(r=0,278$; $p=0,003)$, pertambahan berat badan $(r=0,164 ; p=0,074)$, kadar $\mathrm{Hb}(r=0,136 ; p=0,161)$, dan pengasuhan $(r=0,234$; $p=0,010$ ). Sebaliknya, perkembangan motorik secara bermakna berkorelasi negatif dengan tingkat morbiditas pada bayi $(r=-0,368 ; p=0,000)$. Hasil penelitian di Honduras menjelaskan bahwa pemberian ASI eksklusif menyebabkan perkembangan motorik bayi lebih cepat yang ditunjukkan oleh kemampuan duduk, meraih, merangkak, dan berjalan yang lebih cepat (20).

Pertambahan panjang badan dan berat badan, lama pemberian $\mathrm{ASI}$, kadar $\mathrm{Hb}$, morbiditas, dan pengasuhan memiliki hubungan yang lemah terhadap perkembangan motorik bayi. Hasil yang serupa juga pernah dilaporkan bahwa status gizi (stunted) tidak berhubungan bermakna dengan perkembangan akan tetapi memiliki risiko terhadap keterlambatan perkembangan bahasa (21). Namun, perbaikan pengasuhan, kadar $\mathrm{Hb}$, dan semakin lama pemberian ASI eksklusif dapat memberikan dukungan positif terhadap perbaikan perkembangan motorik bayi.

Dalam penelitian ini juga ditemukan bahwa proporsi bayi yang anemia $(\mathrm{Hb}<110 \mathrm{~g} / \mathrm{L})$ memiliki skor perkembangan motorik yang lebih rendah dibandingkan dengan bayi yang tidak anemia. Hasil penelitian ini menunjukkan pada kelompok fortifikasi tidak ada yang termasuk dalam $\mathrm{Hb}$ kurang. Hasil ini diduga dampak dari pemberian pangan fortifikasi multi gizi mikro pada ibu hamil. Besi juga sangat berperan dalam fungsi neurotransmiter dan penurunan fungsi dopamin. Dopamin adalah komponen neurotransmiter pada otak manusia dan tikus. Hasil penelitian di Kosta Rika (22) menunjukkan bahwa kekurangan fungsi reseptor dopamin berhubungan dengan kekurangan besi. Besi juga sangat penting dalam mielinasi, pada tikus yang mengalami kekurangan besi menunjukkan mielinasi yang rendah (hypomyelination).

Anemia dapat mempengaruhi perkembangan sistem saraf pusat (central neuron system/CNS) pada bayi. Anemia pada bayi sampai umur 6 bulan akan menghambat kematangan sinaptik dan menyebabkan gangguan pada control conduction time (CCT) atau gangguan pengontrolan penyampaian informasi pada saraf sampai umur 24 bulan. Anemia pada bayi umur 6 bulan berhubungan dengan aspek perkembangan CNS dan mielinasi sel saraf selama 2 tahun kehidupan (23). Hasil studi yang dilakukan di 
Afrika Selatan menunjukkan suplementasi besi $(50 \mathrm{mg}) 4$ kali dalam seminggu selama 8,5 bulan pada anak anemia yang berumur 6 sampai 11 tahun dapat memperbaiki perkembangan kognitif dan memori anak (24).

Hasil analisis regresi logistik menunjukkan bahwa faktor-faktor yang mempengaruhi terjadinya respon perkembangan motorik yang baik pada bayi adalah pemberian pangan fortifikasi pada ibu waktu hamil dan tingkat morbiditas atau kesakitan pada bayi. Persentase tertinggi bayi yang mampu mengikuti semua tugas perkembangan motorik diperoleh pada kelompok fortifikasi $(37,5 \%)$, diikuti kelompok tanpa fortifikasi $(30,8 \%)$, dan yang terendah pada kelompok kontrol $(12,5 \%)$. Suplementasi multi gizi mikro yang diberikan pada ibu hamil trimester pertama membuktikan bahwa anak yang dilahirkan memiliki skor psikomotor lebih baik dibandingkan dengan anak yang menerima yodium setelah lahir sampai umur 2 tahun (25). Menurut hasil penelitian di Zanzibar, suplementasi besi dan folat pada bayi yang berumur 5-10 bulan yang diamati perkembangan motoriknya (waktu berjalan) menunjukkan bahwa pencapaian usia berjalan anak dipengaruhi suplementasi besi dan folat yang berhubungan dengan perbaikan status besi dan kadar $\mathrm{Hb}$ pada anak (12).

Hasil penelitian ini menunjukkan bahwa bayi yang lebih rendah skor morbiditasnya $(<146,7)$ memiliki respon perkembangan motorik yang lebih baik $(66,6 \%)$ dibandingkan dengan bayi yang memiliki tingkat morbiditas atau kesakitan tinggi $(\geq 146,7)$. Menurut hasil penelitian di daerah pedesaan Matlab Bangladesh (26), morbiditas dipengaruhi oleh asupan gizi pada masa janin, outcome kelahiran, dan status gizi bayi. Hasil penelitian yang hampir sama juga pernah dilaporkan, di mana suplementasi vitamin A pada anak di Mexico dapat menurunkan morbiditas dan meningkatkan respon imunitas (27). Dengan demikian, semakin tinggi tingkat kesakitan bayi maka perkembangan motorik bayi akan semakin rendah. Hal ini dapat terjadi karena adanya pengaruh negatif kesakitan terhadap pertumbuhan dan perkembangan anak. Kesakitan dapat menurunkan daya guna gizi dalam tubuh sehingga dapat mempengaruhi pertumbuhan dan perkembangan. Selain itu, anak yang sakit cenderung tidak aktif yang akhirnya berdampak pada penurunan perkembangannya. Perkembangan psikomotor dipengaruhi oleh morbiditas (28).

Hasil penelitian lain di Bogor (29) menunjukkan hasil yang sama bahwa suplementasi makanan multi gizi mikro berhubungan dengan perkembangan motorik. Suplementasi besi, seng, iodium, dan folat pada anak dapat meningkatkan perkembangan motorik anak (30). Hasil studi di China menunjukkan bahwa suplementasi iodium selama hamil dapat menurunkan prevalensi kelainan neurologi anak (18). Berbeda dengan penelitian di Thailand yang membuktikan bahwa suplementasi besi dan atau seng pada masa bayi tidak mengarah kepada peningkatan kognitif jangka panjang pada anak-anak setelah berusia 9 tahun (31).

\section{SIMPULAN DAN SARAN}

Persentase tertinggi bayi yang mampu mengikuti semua tugas perkembangan motorik terdapat pada kelompok fortifikasi $(37,5 \%)$, kemudian pada kelompok tanpa fortifikasi $(30,8 \%)$, dan terendah pada kelompok kontrol $(12,5 \%)$. Pemberian pangan fortifikasi zat multi gizi mikro pada saat ibu hamil memberikan respon perkembangan motorik bayi $77 \%$ lebih baik dibandingkan dengan perlakuan lainnya. Bayi yang tidak anemia $(\mathrm{Hb}$ $\geq 110 \mathrm{~g} / \mathrm{L}$ ) memiliki persentase skor perkembangan motorik yang lebih baik dibandingkan dengan bayi yang anemia.

Perlu adanya penelitian lebih lanjut untuk menganalisis dampak pemberian pangan fortifikasi zat multi gizi mikro pada ibu hamil terhadap pertumbuhan dan perkembangan kognitif pada bayi setelah usia 6 bulan. Tetap diperlukan adanya pemberian pangan fortifikasi pada ibu hamil, menyusui, dan balita terutama bagi masyarakat miskin.

\section{UCAPAN TERIMA KASIH}

Terimakasih disampaikan kepada Seafast Center Institut Pertanian Bogor yang telah memberikan bantuan dana untuk penelitian ini.

\section{RUJUKAN}

1. Arifeen SE, Black RE, Caulfield LE, antelman G, Baqui $\mathrm{AH}$, Nahar Q, Alamgir S, Mahmud H. Infant grotwh patterns in the slum Dhaka in relation to birth weight intrauterine growth retardation and prematurity. Am J Clin Nutr 2004;72(4):1010-7.

2. Husaini MA, Jahari $A B$, Heryudarini $H$. Kurva perkembangan gerak motorik kasar semua anak umur 3-18 bulan. Bogor: Puslitbang Gizi; 2004.

3. Badan Koordinasi Keluarga Berencana Nasional. Bahan penyuluhan dan pemantauan perkembangan balita. Bandung: Badan Koordinasi Keluarga Berencana Nasional; 1999.

4. Lumbantobing SM. Anak dengan mental terbelakang. Jakarta: Fakultas Kedokteran, Universitas Indonesia; 1997.

5. Pollit E, Huang JF, Jahari AB. Developmental function of motor activity among nutritionally at-risk children. Food Nutr Bull 1999;1:100-7.

6. Kariger PK, Stoltzfus RJ, Olney D, Sazawal S, Black R, Tielsech JM, Fronggillo EA, Khalfan SS, Pollit E. Iron deficiency and physical growth predict attaintment of walking but not crawling in poorly nourished Zanzibari infants. J Nutr 2005;135(4):814-9. 
7. Siegel EH, Stoltzfus Rj, Kariger PK, Katz J, Khatry SK, LeClerg SC, Pollit E, Tielsech JM. Growth indices anemia and diets independently predict motor milestone acquisition of infant in South Central Nepal. J Nutr 2005;135(12):2840-4.

8. Zulkifli L. Psikologi perkembangan. Bandung: Remaja Rosdakarya; 1995.

9. Departemen Kesehatan RI. Situasi kesehatan dan gizi Indonesia. Jakarta: Departemen Kesehatan Rl; 2004.

10. Grantham-McGregor S, Fernald LC, Sethuraman $K$. Effect of health and nutrition on cognitive and behavioral development in child in the first year of life (Part 1). Food Nutr Bull 1999;20(1):53-75.

11. Beard J. Iron deficiency alters brain development and functioning. J Nutr 2003;133(5 Suppl 1):1468S-72S.

12. Onley DK, Pollitt E, Kariger PK, Khalfan SS, Ali NS, Tielsch JM, Sazawal S, Black R, Allen LH, Stoltzfus RJ. Combined iron and folic acid supplementation with or without zinc reduces time to walking unassisted among Zanzibari infants 5-to 11-mo old. J Nutr 2006;136(9):2427-34.

13. Jarjou LM, Prentice A, Sawo Y, Laskey MA, Bennet J, Goldberg GR, Cole TJ. Randomized placebo-controlled calcium supplementation study in pregnant Gambian women: effect on breast milk calcium concentrations and infant birth weight, growth and bone mineral accretion in the first year of life. Am J Clin Nutr 2006;83(3):657-66.

14. Firlie. Faktor-faktor yang mempengaruhi morbiditas anak baduta pada keluarga miskin dan tidak miskin [Skripsi]. Bogor: Departemen GMSK Institut Pertanian Bogor; 2000.

15. Departemen Kesehatan RI. Deteksi dini penyimpangan perkembangan. Jakarta: Departemen Kesehatan RI; 2005.

16. Administrative Committee on Coordination SubCommittee on Nutrition. Nutrition throughout the life cycle. Fourth report on the world nutrition situation. Geneva: Administrative Committee on Coordination Sub-Committee on Nutrition; 2000.

17. Wegmiller R, Camara F, Zimmermann MB, Adou F, Hurrel RF. Salt dual-fortified wth iodine and micronized ground ferric pyrophosphate affects iron status but not hemoglobin in children in Coted'Ivoire. J Nutr 2006;136(7):1814-20.

18. Allen L, Gillespie S. What works? a review of the efficacy and effectiveness of nutrition intervention. Geneva: Administrative Committee on Coordination Sub-Committee on Nutrition; 2001.

19. Bender DA. Introduction to nutrition and metabolism $3^{\text {rd }}$ edition. London: Taylor and Francis Ltd; 2002.

20. Dewey KG, Cohen RJ, Brown KH. Exclusive breastfeeding for 6 months, with iron supplementation maintains adequate micronutrient status among term, low-birthweight breast-fed infant in Honduras. J Nutr 2004;134(5):1091-8.

21. Hizni A, Julia A, Gamayanti IL. Status stunted dan hubungannya dengan perkembangan anak balita di wilayah pantai utara Kecamatan Lemahwungkuk Kota Cirebon. Jurnal Gizi Klinik Indonesia [serial online] 2010 [cited 2011 Jan 3];6(3):131-7. Available from: URL: http.//www.ijcn.or.id

22. Lozoff $B$. Long-term developmental outcome of infants with iron deficiency. New Eng J Med 1991;325(10):68794.

23. Roncagliolo $M$, Garrido $M$, Walter $T$, Peirano $P$, Lozoff B. Evidence of altered central nervos system development in infants with iron deficiencies anemia at 6-mo: delayed maturition of auditoty brainstem responses. Am J Clin Nutr 1998;68(3):683-90.

24. Baumgartner J, Smuts CM, Malan L, Kvalsvig J, Stujivenberg ME, Hurrell RF, Zimmermann MB. Effects of iron and $n-3$ fatty acid supplementation, alone and in combination, on cognition in school children: a randomized, double-blind, placebocontrolled intervention in South Africa. Am J Clin Nutr 2012;96(6):1327-38.

25. Black RE. Zinc deficiency, immune function, morbidity and mortality from infectious disease among children in developing countries. Special issue on recent intervention trials with zinc. Food Nutr Bull 2001;22(Pt2):1-12.

26. Raqib R, Alam DS, Sarker P, Ahmad SM, Ara G, Yunus M, Moore SE, Fuchs G. Low birth weight is associated with altered immune function in rural Bangladesh children a birth cohort study. Am J Clin Nutr 2007;85(3):845-52.

27. Long KZ, Garcia ET, Rosado JL, Santos JL, Haas M, Firestone M, Bhagwat J, Young C, DuPont HL, Hertzmark E, Nanthakumar NN. Vitamin A supplementation reduces the monocyte chemoattractant protein-1 intestinal immune response of Mexican children. J Nutr 2006;136(10):2600-5.

28. Lechtig A. Nutritional needs and assessment of normal growth. Gracey M, Falkner F (Eds). Nestle Nutrition. New York: Raven Press; 1985.

29. Herawati T. Pengaruh pemberian suplemen biskuit multi gizi ibu hamil terhadap pertumbuhan linier dan perkembangan bayi 0-6 bulan [Tesis]. Bogor: Sekolah Pascasarjana Institut Pertanian Bogor; 2003.

30. Black MM. Micronutrient deficiencies and cognitive function. J Nutr 2003;133(11 Suppl 2):3927S-31S.

31. Pangcharoen T, DiGirolamo AM, Matorel R, Flores $R$. Long-term effects of iron and zinc supplementation during infancy on cognitive function at 9-y of age in northeast Thai children: a follow-up study. Am J Clin Nutr 2011;93(3):636-43. 